\title{
Laser Interferometric Method in the Measurement of Lipopolisaccharides Interactions with Antibacterial Compounds
}

\section{Michał Arabski*}

Department of Microbiology, Jan Kochanowski University, Poland

The aim of my investigations is novel applications of modified laser interferometry method in microbiological, biophysical and biochemical analysis. The measurement system consists of Mach-Zehnder interferometer with a He-Ne laser, a TV-CCD camera and a computer with a system for the acquisition and processing of interference images. The method is based on the phenomenon of diffusion process and linear dependence of the refractive index of the solution concentration. The interference images depend on the refraction coefficient of the solute, which in turn depends on the substance concentration. Laser interferometry might be useful technique in quantitative analysis of antibiotics diffusion (in real time), like ampicilin, ciprofloxacin, streptomycin or colistin, through cellulose and nucleopore membranes (using in clinical practice) as well as in determination of drugs releasing from polymers using as drugs careers [1]. This method was using in the investigation, important from clinical point of view, like the measurement of liposomes diffusion through artificial skin material and cellulose-based wound dressing to optimalization of therapy using liposome encapsulated drugs [2]. Laser interferometry system might be use in analysis of biologically active heteropolymers interactions with biomolecules, like lipopolysaccharides (endotoxin, LPS) with colistin, chitosans or saponins [3-5]. Moreover, I used this technique in verification of ELISA test for the determination of anti-LPS P. mirabilis antibody levels in human sera [6]. The results of investigations obtained by the laser interferometry were verified by cultivation methods using in microbiology, immunoserological assays (dot blot techniques, LAL assay, ELISA), bioinformatics tools, electron microscopy, sucrose gradient centrifugation or in vivo toxicity tests. I concluded that interdisciplinary investigations based on stand art techniques using in microbiology or biochemistry as well as laser interferometry method might give a broad insight to clinical applications of tested drugs.

\section{References}

1. Arabski M, Wasik S, Piskulak P, Góźdź N, Slezak A, et al. (2011) [Analysis of antibiotic diffusion from agarose gel by spectrophotometry and laser interferometry methods]. Polim Med 41: 25-32.

2. Arabski M, Wąsik S, Grześkiewicz H, Drulis-KawaZ, Gubernator J, et al. (2012) Laser interferometric determination of liposome diffusion through artificial membranes, in: Interferometry - Research and Applications in Science and Technology.

3. Arabski M, Wasik S, Dworecki K, Kaca W (2007) Laser interferometric determination of ampicillin and colistin transfer through cellulose biomembrane in the presence of Proteus vulgaris O25 lipopolysaccharide. Journal of Membrane Sciences 299: 268-275.

4. Arabski M, Wąsik S, Dworecki K, Kaca W (2009) Laser interferometric and cultivation methods for measurement of colistin/ampicilin and saponin interactions with smooth and rough of Proteus mirabilis lipopolysaccharides and cells. Journal of Microbiological Methods 77: 178-183.

5. Arabski M, Davydova VN, Wąsik S, Reunov AV, Lapshina LA, et al. (2009) Binding and biological properties of lipopolysaccharide Proteus vulgaris $\mathrm{O} 25$ (48/57)-chitosan complexes. Carbohydrate Polymers 78: 481-487.

6. Arabski M, Fudala R, Koza A, Wasik S, Futoma-Koloch B, et al. (2012) The presence of anti-LPS antibodies and human serum activity against Proteus mirabilis S/R forms in correlation with TLR4 (Thr399lle) gene polymorphism in rheumatoid arthritis. Clin Biochem 45: 1374-1382.
*Corresponding author: Michał Arabski, Department of Microbiology, Jan Kochanowski University, Świętokrzyska, Poland, E-mail: arabski@ujk.edu.pl

Received January 24, 2013; Accepted January 25, 2013; Published January 28, 2013

Citation: Arabski M (2013) Laser Interferometric Method in the Measurement of Lipopolisaccharides Interactions with Antibacterial Compounds. Clin Microbial 2: e108. doi:10.4172/2327-5073.1000e108

Copyright: @ 2013 Arabski M. This is an open-access article distributed under the terms of the Creative Commons Attribution License, which permits unrestricted use, distribution, and reproduction in any medium, provided the original author and source are credited. 